it is not certain that there were not truly sterile plants in the field, but the observations were sufficient to show that a large number of those that would be regarded as sterile at a later date had made an attempt to produce blossoms and had been more nearly successful in the case of the outer leaves than of the sporophylls.

The early development of the buds of spring flowers has been referred to by different writers. Foerste ${ }^{2}$ mentions among the buds collected in Vermont, August 22-28, one of Trillium erythrocarpum $5 \cdot 5^{\mathrm{mm}}$ in length. The present writer found in central New York, on July i r, a flower bud of $T$. grandiflorum $2^{\mathrm{mm}}$ in length, with anthers $1.7^{\mathrm{mm}}$ long. There was no opportunity to learn the stage in the development of the pollen.-Arma A. Sмiтh, Cornell University.

\title{
A STUDY OF SOME ANATOMICAL CHARACTERS OF NORTH AMERICAN GRAMINEÆ. VII.
}

(WITH PLATE XX)

THE GENUS AMPHICARPUM:

OnLy two species are known of this singular genus, $A$. Floridanum Chapm. and A. Purshii Kth., their geographical distribution being limited to the eastern United States, along the Atlantic coast. They both grow in sandy soil, but while $A$. Floridanum does not occur outside the semi-tropical Florida, the other species shows a larger range of distribution, from New Jersey as far south as Georgia. Their manner of growth is different, $A$. Purshii being cespitose, while A. Floridanum is stoloniferous, but otherwise they show a rather similar appearance, especially in regard to their floral characters, both developing their fruits underground, as true geocarpic plants. By comparing their leaf-structure we shall see that according to their distribution, and the character of the soil wherein they grow, the anatomical differences are but slight, and almost wholly dependent upon the development of the epidermis. These divergences, slight as they are, prove nevertheless sufficient to enable us to distinguish the two species anatomically.

AMPHICARPUM FLORIDANUM.-The epidermis of the superior face of the leaf $(f g .2)$ consists generally of thick walled cells, which vary considerably in size and shape according to their disposition, whether ${ }^{1892 .}$. 2 the relations of certain fall to spring blossoming plants, Вот. GAZ. I7: I. 
they belong to the strata that cover the mesophyll or the stereome. Those covering the mesophyll are either developed as bulliform cells ( $B C$, in $f g .2)$ with nearly straight walls, or as ordinary epidermis cells with numerous stomata $(S$, in $f g .2)$. The cells of the stomatiferous strata have distinctly undulate cell walls, and these strata form longitudinal bands on both sides of the bulliform cells. Very different from these strata are those which cover the stereome ( $A$, in $f g .2)$. Here we find cells of very different size, short and almost fusiform, or rather long, but all showing numerous foldings of the cell walls. Two forms of epidermal expansions are to be found here, viz., some which are short, one-celled and thorn shaped, and small hairs consisting of two cells $(H$, in $f g .2)$. This structure is to be found on the entire surface of the leaf in regular alternation and with almost the same number of rows in each stratum ( $f g .2)$. There is in this way nothing to indicate the median part of the blade, for it shows no larger development of the bulliform cells, and, as will be shown later, the median mestome bundle and its surroundings do not show any histological difference from those of the lateral parts of the blade.

If we consider the epidermis of the inferior face of the leaf we find only a few differences from that of the superior one. The hairs seem here to be most frequent in the stomatiferous strata; the cells which surround the stomata are exceedingly thick walled, and no proper bulliform cells are developed, so that the stomatiferous strata occupy the entire space between those which cover the stereome. As shown in fig. 3 , the epidermis of the inferior face shows a certain development approaching that of bulliform cells, but widely different from $A$. Purshii, which exhibits true bulliform cells on the inferior face of the blade.

The mestome bundles are of a very uniform development, and, as stated above, the median bundle is not more prominent than the others. Only two forms may be distinguished, but the difference is relatively smaller than we have seen in the other genera described in our previous articles upon this subject. Both forms of mestome bundles are surrounded by a completely closed and colorless parenchyma sheath $(P$, in $f g .5)$, inside of which is a mestome sheath of thick walled cells. The larger bundles show the presence of a single layer of thick walled mestome parenchyma, separating the leptome from the hadrome; and in the smaller bundles this parenchyma is absent. The smaller bundles appear to be the more numerous. 
The stereome $(S t$, in $f i g .5)$ is well developed in this genus, and forms groups above and below each mestome bundle. On the inferior face of the leaf the stereome is sometimes bordering immediately on the parenchyma sheath, but is also seen to be separated from this either by the adjoining mesophyll or by colorless parenchyma. The stereome of the superior face is constantly separated from the parenchyma sheath by one to three cells of colorless parenchyma. The stereome has attained its highest development, however, along the margins of the blade $(f i g .4)$. We see here an enormous group of this tissue connecting the two faces of the leaf, and by this character Amphicarpum is readily distinguished from any of the other genera which we have previously examined and described.

The mesophyll occupies quite an extensive part of the leaf blade, and forms usually separate groups between the mestome bundles, excepting where it passes uninterruptedly underneath these, between the stereome and the parenchyma sheath. It forms a compact tissue with the cells radiating from the mestome bundles, and no lacunes are observable. The colorless parenchyma has already been touched upon above, and we have seen it developed as a closed parenchyma sheath and as small groups or single cells between the stereome and the mestome bundles. As shown in fig. I, it has attained its highest development on the superior part of the leaf.

Amphicarpum Purshit. - The epidermis of both faces of the leaf shows very nearly the same structure as we have described for $A$. Floridanum, but we note the following differences: The bulliform cells are here equally well developed on both faces $(f g .6)$; epidermal expansions as very long unicellular hairs are frequent on both faces, and are especially common in the bulliform strata. The thorn shaped expansions in this species seem to be most common in the stomatiferous strata, near the bulliform cells. The mestome bundles do not seem to differ from those of the other species, and the same is true of the mesophyll and the stereome. The colorless parenchyma is less developed on the superior face than we have seen in A. Floridanum. Fig. 6 represents a transverse section of the median part of the leaf, and we see here only one single cell of colorless parenchyma above the parenchyma sheath, while below this the sheath borders immediately on the stereome.

In comparing the leaf structure of these two species of Amphicarpum, the principal anatomical differences are as follows: 


\section{Epidermis-}

Long unicellular hairs on both faces - _ _ _ A. Purshii

No long hairs

A. Floridanum

Bulliform cells well developed on both faces of the leaf A. Purshit

These restricted to the superior face

A. Floridanum

\section{Mesophyll -}

Forming separate groups between the mestome bundles A. Purshii

Sometimes united

A. Floridanum

Colorless parenchyma -

Small groups separating the stereome of the superior face from the parenchyma sheath - - - A. Floridanum

Frequently only a single cell _ _ _ _ _ $\quad$ - A.Purshii

The leaf is altogether thicker and of firmer structure in A. Floridanum than in A. Purshii, a fact that perhaps indicates the warmer and drier climate of the region to which $A$. Floridanum belongs.-Theo. Holm, Washington, D. C.

\section{EXPLANATION OF PLATE XX.}

FIGS. I-5. Transverse sections of the leaf of Amphicarpum Floridanum.

Fig. I. The median part of the blade, showing fine mestome bundles and fine groups of bulliform cells on the superior face; Sup, the superior face. $\times 165$.

FIG. 2. Epidermis of the superior face, seen en face; $B C$, bulliform cells; $S$, the stomatiferous strata; $A$, the strata which cover the stereome; $H$, a hair. $\times 500$.

FIG. 3. Group of epidermis cells from the inferior face, showing a structure somewhat similar to that of proper bulliform cells. $\times 500$.

FIG. 4. The margin of the blade, showing the enormous development of stereome. $\times 330$.

FIG. 5. One of the largest mestome bundles; $P$, the colorless parenchyma sheath; $S t$, the stereome; $E p$, the epidermis. $\times 330$.

FIg. 6. Transverse section of the leaf of $A$. Purshii, showing three mestome bundles and three groups of bulliform cells on both faces; Sup, the superior face. $\times 165$. 


\section{$2 \mathrm{BHL}$ Biodiversity Heritage Library}

1896. "A Study of Some Anatomical Characters of North American Gramineæ. VII." Botanical gazette 22(5), 403-406. https://doi.org/10.1086/327430.

View This Item Online: https://www.biodiversitylibrary.org/item/93711

DOI: https://doi.org/10.1086/327430

Permalink: https://www.biodiversitylibrary.org/partpdf/222681

\section{Holding Institution}

Missouri Botanical Garden, Peter H. Raven Library

\section{Sponsored by}

Missouri Botanical Garden

\section{Copyright \& Reuse}

Copyright Status: Public domain. The BHL considers that this work is no longer under copyright protection.

This document was created from content at the Biodiversity Heritage Library, the world's largest open access digital library for biodiversity literature and archives. Visit BHL at https://www.biodiversitylibrary.org. 